\title{
AOR
}

Selected Papers of \#AolR2021:

The 22nd Annual Conference of the

Association of Internet Researchers

Virtual Event / 13-16 Oct 2021

\section{PERFORMING LIFESTYLE POLITICS: EXPLORING THE SLOW FASHION COMMUNITY ON INSTAGRAM}

Jimil Ataman

University of Pennsylvania

\section{Introduction}

Type "\#slowfashion" into Instagram's 'most popular' search function and you will be met with approximately 8.5 million photos. At first glance slow fashion Instagram appears to consist mostly of perfectly manicured photos of highly curated outfits, accessories or clothing. But to those in the slow fashion community, these posts also indicate a unique discursive register (Agha 2007) that includes a set of political, ethical and social repertoires, emerging through the formation of the movement's lifestyle politics (Portwood-Stacer 2013). This paper explores three key performable roles being taken up by slow fashion practitioners on Instagram to analyze how these performances are positioned within the community's broader ethical and political goals.

\section{Background}

The slow fashion movement is based on the model of the slow food movement, which emerged in response to its 'fast' counterpart (Jung and Jin 2016). It includes people, practices, ideas, and things from all over the world and online - all of which are broadly connected through a shared effort to resist and transform the waste-driven, profitseeking, inequitable and unjust systems which produce and sustain contemporary 'fast' fashion (Pookulangara and Shephard 2013; Štefko and Steffek 2018; Clark 2008). The fast fashion industry is a system of transnational capitalism in which the supply chains of labor and commodities span dozens of countries (Rofel and Yanagisako 2019), rely on the exploitation of garment workers in low-income countries in the global south (Collins 2003) and reproduce unattainable Western beauty standards to keep production costs low and demand high (Jung and Jin 2016; Entwistle 2000). Most apparel today is produced through the fast fashion business model wherein clothing is made and marketed through cycles of inexpensive ready-to-wear garments (Krause 2018). This model proliferates a capitalist consumer ethic (Campbell 1987) where desire and novelty fuel the repetitive cycle of buying and discarding mass-produced garments (Dei Ottai and Cologna 2015; Reinach 2005). The result? The fashion industry has become a major contributor to global pollution (Niinimäki et al 2020), yielding 1.2 billion

Suggested Citation (APA): Ataman, J., (2021, October). Performing Lifestyle Politics: Exploring the Slow Fashion Community on Instagram. Paper presented at AoIR 2021: The 22nd Annual Conference of the Association of Internet Researchers. Virtual Event: AolR. Retrieved from http://spir.aoir.org. 
tons of $\mathrm{CO} 2$ to the atmosphere and over 80 billion pieces of discarded, often unworn clothing into landfills each year (Whitty 2018).

\section{Performing Lifestyle Politics}

Since 2014, the slow fashion community has coalesced on Instagram, bringing together four groups of entangled practitioners: brands, consumers, influencers, and DIY makers interested in advocating for clothing-sustainability, ethical-fashion, representationdiversification in the fashion industry, economic justice, and anti-capitalism. Recently slow fashion practitioners have been using their slow fashion performances to publicly navigate issues of race, class, gender, and ethics present in slow fashion and the broader fashion industry. They do so using tactics of lifestyle practices (PortwoodStacer 2013) in which individuals integrate the "movement's values into a holistic way of life" (Haenfler et al. 2012: 7). As slow fashion practitioners are performing their lifestyle practices on Instagram, they are also performing a presentation of their selves. Selfpresentation produces a "coherent and distinctive way of 'being-in-the-world"' (Clarke, 2005: 54). Because so much of contemporary slow fashion is coalescing on the online platform Instagram, where the politics of the internet, including issues of the commodification of internet users (Lukás 2020) datafication (van Dijck 2014), and selfpromotion (Marwick 2013) are at play, the slow fashion movement is a uniquely representative site of a constantly changing and continuously developing contemporary political practice.

Using case studies from my ongoing ethnographic research which follows the coalition of practitioners on Instagram and in the Pacific Northwest - I explore three key performable roles in the slow fashion community which slow fashion practitioners are using as a way to perform the politics of the movement: (1) Outfit of the Day Posts (OOTD), (2) wardrobe tracking, and (3) knowledge-sharing posts. In discussing each of these instances of popular slow fashion performances, I examine what each example is "saying" and "doing" within the slow fashion community and analyze how these performances are positioned within the community's broader ethical and political goals. Further, my discussion offers insight into how these performances are producing avenues for a slow fashion practice aimed at consuming differently and connecting a community of people advocating for alternative modes of fashion production.

Ultimately, this discussion adds to the emerging scholarship on slow fashion by exploring how slow fashion on Instagram is producing a set of identifiable repertoires of communication which index the larger political and ethical principles being constructed by the community in response to the capitalist structures in which it is housed. By exploring the kinds of performances most commonly posted on Instagram I draw attention to the ways slow fashion practitioners' performances are both assembling individual practitioner identity (or 'self') to the wider slow fashion community as well as producing a wider register of lifestyle politics in the world at large.

\section{References}


Campbell, Colin. 1987. The romantic ethic and the spirit of modern consumerism. Oxford, UK: B. Blackwell.

Clark, Hazel. 2008. "Slow Fashion - an oxymoron - or a promise for the future?" Fashion Theory 12 (4): 427-446.

Collins, Jane. 2003. Threads: Gender, Labor, and Power in the Global Apparel Industry. Chicago: The University of Chicago Press.

Dei Ottai, Gabi and Daniel Brigadio Cotogna. 2015. "The Chinese in Prato and the Current Outlook on the Chinese-Italian Experience." In Chinese Migration to Europe: Prato, Italy and Beyond, edited by Loretta Baldassar, Graeme Johanson, Narelle McAuliffe, and Masimo Bressan, 29-48. New York: Palgrave Macmillan.

Entwistle, Joanne. 2000. The Fashioned Body: Fashion, Dress, and Modern Social Theory. Malden, MA: Blackwell.

Jung, Sojin; and Byoungho Jin. 2016. "From quantity to quality: understanding slow fashion consumers for sustainability and consumer education." International Journal of Consumer Studies, 40 (4): 410- 421.

Krause, Elizabeth. 2018. Tight Knit: Global Families and The Social Life of Fast Fashion. Chicago: The University of Chicago Press.

Lukács, Gabriella. 2020. Invisibility by Design: Women and Labor in Japan's Digital Economy. Durham: Duke University Press.

Marwick, Alice. 2013. Status Update: Celebrity, Publicity, \& Branding in the Social Media Age. New Haven \& London: Yale University Press.

Niinimäki, Kirsi, Greg Peters, Helena Dahlbo, Patsy Perry, Timo Rissanen, and Alison Gwilt.2020. "The Environmental Price of Fast Fashion." Nature Reviews Earth \& Environment 1 (4): 189-200.

Overdiek, Anja. 2018. "Opportunities for Slow Fashion Retail in Temporary Stores." Journal of Fashion Marketing and Management 22 (1): 67-81. https://doi.org/10.1108/JFMM-05-2017-0042.

Pookuangara, Sanjukta; and Arlesa Shepard. 2013. "Slow fashion movement: Understanding consumer perceptions-An exploratory study." Journal of Retailing and Consumer Services, 20: 200-206.

Reinach, Simona Segre. 2005. "China and Italy: Fast Fashion versus Prêt à Porter. Towards a New Culture of Fashion." Fashion Theory: The Journal of Dress, Body \& Culture 9(1): 43-56. 
Rofel, Lisa, and Sylvia J. Yanagisako. 2019. Fabricating transnational capitalism: a collaborative ethnography of Italian-Chinese global fashion. Durham, NC: Duke University Press.

Štefko, Róbert; and Vladimira Steffek. 2018. Key issues in Slow Fashion: Current challenges and future perspectives. Sustainability 2018, vol. 10, no. 7. pp. 1-11. doi:10.3390/su10072270

van Dijck, José. 2014. Datafication, dataism and dataveillance: Big Data between scientific paradigm and ideology. Surveillance \& Society 12(2): 197-208.

Whitty, Jennifer. 2018. "Wardrobe Hack and Uncatwalk: Design interventions to encourage more fulfilling relationships with our clothing." Clothing Cultures 5(1): $131-151$. 